\title{
The effect of long-term feeding of soya-bean flour diets on pancreatic growth in the rat
}

\author{
BY ROSA A. CRASS AND R. G. H. MORGAN \\ Department of Physiology, University of Western Australia, Nedlands, 6009, \\ Western Australia, Australia
}

(Received 4 April 1981- Accepted 21 September 1981)

\begin{abstract}
1. Pancreatic growth was measured in rats by changes in pancreatic weight, nucleic acid content and protein content after feeding diets of heated soya-bean flour (HSF), raw soya-bean flour (RSF), $200 \mathrm{~g}$ raw soya-bean flour $+800 \mathrm{~g}$ heated soya-bean flour $/ \mathrm{kg}(80 \mathrm{HSF})$ and $400 \mathrm{~g}$ raw soya-bean flour $+600 \mathrm{~g}$ heated soya-bean flour $/ \mathrm{kg}$ (60 HSF) for periods up to 36 weeks. Control rats of comparable age to soya-bean flour-fed rats were continued on rat cubes during the 36-week study.

2. Cube-fed rats remained significantly heavier than rats fed on soya-bean flour diets. Analysis of variance showed rats fed on HSF were significantly heavier than RSF-fed rats and rats fed on 80 HSF significantly heavier than those fed on $60 \mathrm{RSF}$.

3. Pancreatic indices in HSF-fed rats were similar to comparable control rats.

4. Hypertrophy was found in rats fed on the RSF-containing diets with the extent of enlargement corresponding to the RSF content. Hyperplasia was also found in rats fed on RSF and $60 \mathrm{HSF}$.

5. The greatest pancreatic growth was seen in RSF-fed rats with all the indices peaking at 8 weeks followed by a decline and then a rise again at 36 weeks.

6. The fall in pancreatic indices in rats fed on RSF for 12 and 24 weeks is most likely an effect of general malnutrition due to the multiple deficiences in amino acids which occur in animals fed on RSF. The rise at 36 weeks may reflect increased body growth or the beginning of adenomatous changes.
\end{abstract}

Many studies have shown that diets containing raw soya-bean meal produce pancreatic enlargement in the chicken (Chernick et al. 1948; Saxena et al. 1963; Salman et al. 1968; Madar \& Klein, 1979) and the rat (Booth et al. 1960; Konijn \& Guggenheim, 1967; Bredenkamp \& Luck, 1969; Beswick et al. 1971; Melmed et al. 1976). This effect has been variously ascribed to acinar cell hypertrophy (Chernick et al. 1948; Booth et al. 1960; Saxena et al. 1963; Konijn \& Guggenheim, 1967; Beswick et al. 1971), hyperplasia (Salman et al. 1968; Bredenkamp \& Luck, 1969; Madar \& Klein, 1979) or a mixture of both processes (Melmed et al. 1976). It is due to the presence of heat-labile trypsin inhibitors in the soya-bean flour (Rackis, 1965). Heated soya-bean flour does not cause pancreatic enlargement (Fölsch et al. 1974).

Recently it has been shown that long-term feeding of raw soya-bean flour (RSF) potentiates the action of pancreatic carcinogens (Morgan et al. 1977; Levison et al. 1979) and that over very long periods RSF alone leads to an increased incidence of pancreatic neoplasms apparently of acinar cell origin (McGuinness et al. 1980). If RSF feeding causes acinar cell hyperplasia, the potentiation of carcinogens might be explained since dividing cells are usually more sensitive to the action of carcinogens.

This paper reports the effects of up to 36 weeks exposure to diets of varying RSF content on pancreatic growth, measured by changes in pancreatic weight, DNA, RNA and protein content. Both hypertrophy and hyperplasia were found with RSF-containing diets. 


\section{METHODS AND MATERIALS}

\section{Animals}

Male albino rats originally derived from the Wistar strain were used for these studies. The animals were approximately 12 weeks old, with an average weight of $200 \mathrm{~g}$ at the beginning of each dietary study. They were housed in large wire-mesh cages containing no more than 24 rats per cage and allowed free access to food and water.

\section{Diets}

There were five treatment groups fed differing diets as follows: group 1 were given (W. H. Milne and Co. Pty Ltd, Welshpool, Western Australia) normal rat cubes and animals were killed at the start of the study when they weighed 200-250 g (approximately 12 weeks old; young rats) and at 12,24 and 36 weeks after the commencement of the study; group 2 were given RSF and animals were killed at 1, 2, 4, 8, 12, 24 and 36 weeks after commencement of the RSF diet; group 3 were given heated soya-bean flour (HSF) and animals were killed at 1,2, 4, 8, 12, 24 and 36 weeks after commencement of the HSF diet; group 4 were given $200 \mathrm{~g} \mathrm{RSF}+800 \mathrm{~g} \mathrm{HSF} / \mathrm{kg}(80 \mathrm{HSF})$ and animals were killed at 12 , 24 and 36 weeks after commencement of the $80 \mathrm{HSF}$ diet; group 5 were given $400 \mathrm{~g}$ $\mathrm{RSF}+600 \mathrm{~g} \mathrm{HSF} / \mathrm{kg}(60 \mathrm{HSF})$ and animals were killed at 12, 24 and 36 weeks after commencement of the $60 \mathrm{HSF}$ diet. In addition, a group of older rats was studied; this group, group 6 consisted of 18 rats approximately 1 year old which had been fed on a diet of rat cubes since weaning and was used to study the effects of an RSF diet on the pancreas of old rats. Five rats were fed on RSF for 2 weeks and 4 rats were fed on RSF for 4 weeks. The remaining 9 rats were left on a cube diet and used as controls. Four controls were killed at the time of the 2-week RSF-fed rats and five were killed at the time of the 4-week RSF-fed rats.

RSF and HSF were supplied by Soy Products of Australia Pty Ltd, Bayswater, Victoria, Australia and supplemented with vitamins and minerals as recommended by Fölsch \& Wormsley (1974). The suppliers stated that HSF was prepared by steam-heating RSF under pressure at $250^{\circ}$ for $20-35$ min followed by gradually drying back to $40-60 \mathrm{~g}$ moisture $/ \mathrm{kg}$ in order to destroy most of the soya-bean trypsin inhibitor in the flour. Trypsin inhibitor assay by the method of Kakade et al. (1969) showed insignificant inhibition of trypsin by $1 \mathrm{~g}$ cube diet or HSF while approximately $40 \mathrm{mg}$ trypsin was inhibited by $1 \mathrm{~g} \mathrm{RSF}$.

The composition of soya-bean flours and cubes is shown in Table 1.

\section{Injections}

During the long-term studies $(12,24$ and 36 weeks) rats received weekly intraperitoneal injections of either saline $(9 \mathrm{~g}$ sodium chloride/l) or the pancreatic carcinogen azaserine ( $5 \mathrm{mg} / \mathrm{kg}$ body-weight in $0.25 \mathrm{ml}$ saline/injection) during the first 24 weeks of the study. Rats receiving azaserine injections were not housed in separate cages from those receiving saline injections. The short-term rats (1-8 weeks) in groups 2 and 3 received no injections and were housed in separate cages from the injected rats. Over the time-course covered in these studies there were no differences in pancreatic weight, RNA, DNA or protein between azaserine- and saline-injected rats, therefore the two treatments were combined for analysis.

\section{Removal of pancreas}

In groups 1-5 pancreatic secretion studies were performed before the removal of the pancreas. These animals were fasted overnight (18-24 h) with free access to water $(4.5 \mathrm{~g} \mathrm{NaCl} / 1)$. They were then anaesthetized by intraperitoneal injections of $1.25 \mathrm{~g}$ urethane $/ \mathrm{kg}$ body-weight given as a solution $(250 \mathrm{~g} / \mathrm{l}$ sterile physiological saline). Secretion 
Table 1. Composition of diets

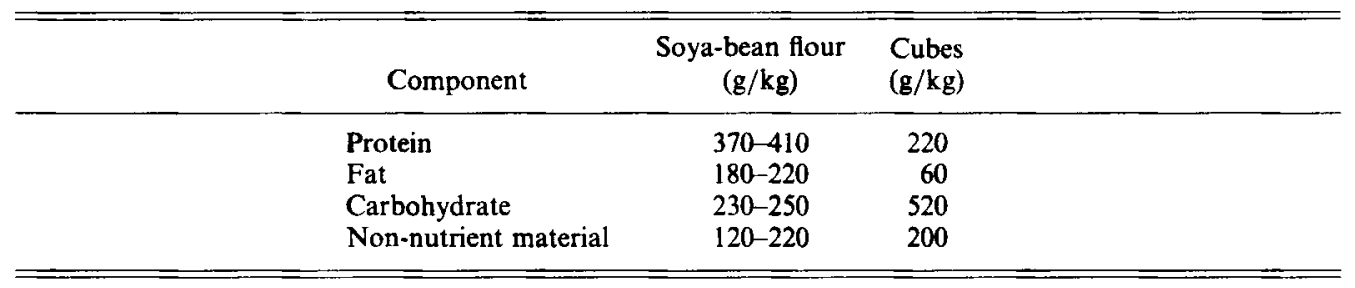

Table 2. Pancreatic indices in stimulated and unstimulated rat pancreas (cube-fed) (Mean values with their standard errors)

\begin{tabular}{lcccccc}
\hline Treatment & $\begin{array}{c}\text { No. of } \\
\text { rats }\end{array}$ & $\begin{array}{c}\text { Body-wt } \\
(\mathrm{g})\end{array}$ & $\begin{array}{c}\text { Pancreatic } \\
\text { wt } \\
(\mathrm{g})\end{array}$ & $\begin{array}{c}\text { DNA } \\
(\mathrm{mg})\end{array}$ & $\begin{array}{c}\text { RNA } \\
(\mathrm{mg})\end{array}$ & $\begin{array}{c}\text { Protein } \\
(\mathrm{mg})\end{array}$ \\
\hline Stimulated & 3 & $346 \pm 9 \cdot 8$ & $1 \cdot 257 \pm 0 \cdot 065$ & $3 \cdot 78 \pm 0 \cdot 78$ & $23 \cdot 3 \pm 2 \cdot 1$ & $204 \pm 8 \cdot 7$ \\
Unstimulated & 4 & $360 \pm 14 \cdot 0$ & $1 \cdot 166 \pm 0 \cdot 064$ & $3 \cdot 77 \pm 0 \cdot 34$ & $21 \cdot 7 \pm 1 \cdot 4$ & $197 \pm 13 \cdot 4$ \\
\hline
\end{tabular}

was studied by the method of Dockray (1972) beginning $3 \mathrm{~h}$ after the anaesthetic and lasting for $2 \mathrm{~h}$. During these studies the pancreas was stimulated with three intravenous doses (5, 10 and 20 Crick-Harper-Raper units) of cholecystokinin (Boots Drug Co., UK). At $5 \mathrm{~h}$ after the administration of the anaesthetic the pancreas was withdrawn through a midline incision and observed. The heart was incised, the pancreas removed, trimmed and weighed. Two pieces of pancreatic tissue, one from the duodenal area and one from the splenic area, each weighing approximately $100 \mathrm{mg}$ were removed for estimation of DNA, RNA and protein. The remainder of the pancreas was placed in ice-cold buffered saline formalin $(100 \mathrm{ml} / \mathrm{l})$ for histology. The effect of the dietary regimens and azaserine treatment on pancreatic histology and secretion will be reported separately.

Preliminary studies showed that cholecystokinin (CCK) stimulation by the schedule used here did not significantly alter pancreatic weight, DNA, RNA or protein content (Table 2). In group 6, secretion studies were not performed and the rats were anaesthetized with diethyl ether before the pancreas was removed.

\section{Analytical methods}

Each piece of tissue from the pancreas was processed separately. RNA, DNA and protein were separated by a modification of the method of Schmidt \& Thannhauser (Hutchinson \& Munro, 1961; Munro \& Fleck, 1966). The tissue was homogenized in cold 0.3 M-perchloric acid (PCA) followed by two washes with the same concentration of acid to extract low-molecular-weight-acid-soluble compounds. The tissue residue was digested in $0 \cdot 3$ M-sodium hydroxide for $1 \mathrm{~h}$ at $37^{\circ}$. At the end of the alkaline digestion a sample was removed for protein determination using the method of Schacterle \& Pollack (1973). The alkaline-digestion fraction was cooled in ice, acidified with $3 \mathrm{M}$-PCA and centrifuged. RNA was determined by measuring the absorption at $260 \mathrm{~nm}$ of the acid-soluble supernatant fraction. The DNA-containing precipitate formed after the acidification was digested in $0 \cdot 8$ $\mathrm{M}-\mathrm{PCA}$ at $70^{\circ}$ for $45 \mathrm{~min}$ to resolubilize DNA. DNA was estimated in a portion of the supernatant fraction with diphenylamine by the method of Hatcher \& Goldstein (1969) using DNA from salmon testes (Sigma Chemical Co.) as standard. 
Table 3. Analysis of variance: partitioning of variance

\begin{tabular}{|c|c|c|c|c|c|c|}
\hline & & $\begin{array}{c}\text { Body } \\
\text { weight }\end{array}$ & $\begin{array}{c}\text { Pancreatic } \\
\text { weight }\end{array}$ & $\begin{array}{c}\text { Pancreatic } \\
\text { RNA }\end{array}$ & $\begin{array}{c}\text { Pancreatic } \\
\text { DNA }\end{array}$ & Protein \\
\hline \multicolumn{7}{|c|}{ Short term } \\
\hline \multicolumn{2}{|l|}{ Main effects: } & & & & & \\
\hline Raw $v$. heated & (I) & * & * & * & * & * \\
\hline 1 week v. 2 week & (II) & & & & & * \\
\hline 2 week is 4 week & (III) & * & & & & \\
\hline 4 week v. 8 week & (IV) & * & & & & \\
\hline \multicolumn{7}{|l|}{ Interactions: } \\
\hline $\mathrm{I} \times \mathrm{II}$ & & & & & & \\
\hline $\mathrm{I} \times \mathrm{III}$ & & * & * & * & & * \\
\hline \multirow{2}{*}{$\mathrm{I} \times \mathrm{IV}$} & \multirow{2}{*}{\multicolumn{5}{|c|}{${ }^{*} \quad$ Long term }} & * \\
\hline & & & & & & \\
\hline \multicolumn{7}{|l|}{ Main effects: } \\
\hline Raw $v$. heated & (1) & * & * & * & * & * \\
\hline $80 \mathrm{HSF} v, 60 \mathrm{HSF}$ & (II) & * & & * & & * \\
\hline Raw v. cube & (III) & * & * & * & * & * \\
\hline Heated v. $60 \mathrm{HSF}$ & (IV) & & * & * & * & * \\
\hline 12 weeks $v .24$ weeks & (V) & * & & & & * \\
\hline \multirow{2}{*}{\multicolumn{7}{|c|}{ Interactions: }} \\
\hline & & & & & & \\
\hline $\mathrm{I} \times \mathrm{V}$ & & & & & & * \\
\hline $\mathrm{I} \times \mathrm{VI}$ & & & & & * & * \\
\hline II $\times \mathrm{V}$ & & & & & & $*$ \\
\hline \multicolumn{7}{|l|}{$\mathrm{II} \times \mathrm{VI}$} \\
\hline \multicolumn{7}{|l|}{$\mathrm{III} \times \mathrm{V}$} \\
\hline \multirow{2}{*}{\multicolumn{7}{|c|}{$\begin{array}{l}\mathrm{III} \times \mathrm{VI} \\
\mathrm{IV} \times \mathrm{V}\end{array}$}} \\
\hline & & & & & & * \\
\hline IV $\times$ VI & & & & & & \\
\hline
\end{tabular}

$* P<0.05$.

Statistical analysis

In the main studies (groups 1-5) values at each time interval were analysed by analysis of variance, with partitioning of variance as set out in Table 3. Differences were tested by the F-test and were considered to be significant if $P<0.05$. In the study with older rats (group 6) differences were tested by $t$ test.

\section{RESULTS}

Body-weight and pancreatic weight

The body-weight and pancreatic weight for groups $1-5$ at the various times studies are shown in Tables 4 and 5.

At all times tested animals fed on cubes were heavier than those fed on soya-bean flour diets. Analysis of variance showed that within the soya-bean-fed groups HSF-fed animals were significantly heavier than RSF-fed animals in both short and long term studies, and $80 \mathrm{HSF}$-fed rats were significantly heavier than $60 \mathrm{HSF}$-fed rats in the long term study. It also showed a significant difference between the body-weight of cube-fed and RSF-fed rats in the long term study.

In RSF-fed animals pancreatic weight fluctuated, increasing to a maximum at 8 weeks ( $220 \%$ value for cube-fed rats), falling at 12 and 24 weeks and then rising again at 36 weeks (Fig. 2). Nevertheless, in both the short and long term studies pancreatic weight was greater in RSF-fed rats than in rats fed on HSF (Table 3). In the long term studies pancreatic weight 
Table 4. The effect of short-term feeding of raw $(R S F)$ and heated $(H S F)$ soya-bean flour on body growth and pancreatic growth in rats

(Mean values with their standard errors; no. of rats in parentheses)

\begin{tabular}{|c|c|c|c|c|c|c|c|c|c|}
\hline \multirow[b]{3}{*}{ Group* } & \multirow[b]{3}{*}{ Diet* $^{*}$} & \multicolumn{8}{|c|}{ Period of feeding (weeks) } \\
\hline & & \multicolumn{2}{|c|}{1} & \multicolumn{2}{|c|}{2} & \multicolumn{2}{|c|}{4} & \multicolumn{2}{|c|}{8} \\
\hline & & Mean & SE & Mean & $\mathrm{SE}$ & Mean & SE & Mean & SE \\
\hline \multicolumn{10}{|c|}{ Body-wt (g) } \\
\hline 1 & Cube & 230 & $6.9(8) \dagger$ & & & & & & \\
\hline 2 & RSF & 192 & $7 \cdot 7(4)$ & 207 & $7 \cdot 7(4)$ & 226 & $7 \cdot 7(4)$ & 246 & $7 \cdot 7(4)$ \\
\hline 3 & HSF & 213 & $5 \cdot 8(7)$ & 231 & $7 \cdot 7(4)$ & 242 & $6 \cdot 9(5)$ & 290 & $5 \cdot 1(9)$ \\
\hline \multicolumn{10}{|c|}{ Pancreatic wt (g) } \\
\hline 1 & Cube & 0.883 & $0.034 \uparrow$ & & & & & & \\
\hline 2 & RSF & $1 \cdot 357$ & $0 \cdot 080$ & 1.426 & 0.080 & 1.616 & 0.080 & 1.943 & 0.080 \\
\hline 3 & HSF & 0.897 & 0.060 & 0.997 & 0.080 & 0.925 & 0.071 & $1 \cdot 046$ & 0.053 \\
\hline
\end{tabular}

* For details, see Table 1 and p. 120.

$\dagger$ Cube-fed animals measured at the start of the study, approximately 3 months old.

Table 5. The effect of long-term feeding of soya-bean flour diets on body growth and pancreatic growth in rats

(Mean values with their standard errors; no. of rats in parentheses)

\begin{tabular}{|c|c|c|c|c|c|c|c|}
\hline \multirow[b]{3}{*}{ Group* } & \multirow[b]{3}{*}{ Diet* } & \multicolumn{6}{|c|}{ Period of feeding (weeks) } \\
\hline & & \multicolumn{2}{|c|}{12} & \multicolumn{2}{|c|}{24} & \multicolumn{2}{|c|}{36} \\
\hline & & Mean & SE & Mean & SE & Mean & SE \\
\hline \multicolumn{8}{|l|}{ Body-wt (g) } \\
\hline 1 & Cube & 312 & $8 \cdot 1(8)$ & 343 & $8 \cdot 7(9)$ & 375 & $9 \cdot 4(6)$ \\
\hline 2 & RSF & 254 & $6 \cdot 6(12)$ & 280 & $7 \cdot 6(9)$ & 295 & $6.9(11)$ \\
\hline 3 & HSF & 280 & $9 \cdot 4(6)$ & 291 & $8 \cdot 1(8)$ & 328 & $8 \cdot 1(8)$ \\
\hline 4 & $80 \mathrm{HSF}$ & 284 & $9 \cdot 4(6)$ & 317 & $8 \cdot 1(8)$ & 347 & $8 \cdot 1(8)$ \\
\hline 5 & $60 \mathrm{HSF}$ & 284 & $8 \cdot 1(8)$ & 302 & $8 \cdot 1(8)$ & 330 & $8.7(8)$ \\
\hline \multicolumn{8}{|c|}{ Pancreatic wt (g) } \\
\hline 1 & Cube & $1 \cdot 118$ & 0.108 & $1 \cdot 307$ & $0 \cdot 115$ & $1 \cdot 168$ & 0.125 \\
\hline 2 & RSF & $1 \cdot 760$ & 0.088 & $1 \cdot 852$ & 0.102 & $2 \cdot 160$ & 0.092 \\
\hline 3 & HSF & $1 \cdot 046$ & 0.125 & 1.034 & 0.108 & $1 \cdot 226$ & 0.108 \\
\hline 4 & $80 \mathrm{HSF}$ & $1 \cdot 339$ & 0.125 & 1.559 & 0.108 & 1.630 & $0 \cdot 108$ \\
\hline 5 & $60 \mathrm{HSF}$ & 1.678 & $0 \cdot 108$ & $1 \cdot 586$ & 0.108 & 1.685 & 0.115 \\
\hline
\end{tabular}

RSF, raw soya-bean flour; HSF, heated soya-bean flour; $80 \mathrm{HSF}, 200 \mathrm{~g} \mathrm{RSF}+800 \mathrm{~g} \mathrm{HSF} / \mathrm{kg} ; 60 \mathrm{HSF}, 400 \mathrm{~g}$ $\mathrm{RSF}+600 \mathrm{~g} \mathrm{HSF} / \mathrm{kg}$

* For details, see Table 1 and p. 120.

over all was greater in RSF-fed compared with cube-fed animals. Between weeks 24 and 36 pancreatic weight increased in RSF-fed rats and decreased slightly in cube-fed rats (Table 5), leading to the significant interaction shown in Table 3. Pancreatic weight was also significantly heavier in rats fed $60 \mathrm{HSF}$ compared with those fed HSF in the long term studies.

There was a significant correlation between body-weight and pancreatic weight in animals fed on HSF and in animals fed on RSF (Fig. 1) though the slope of the regression line for 


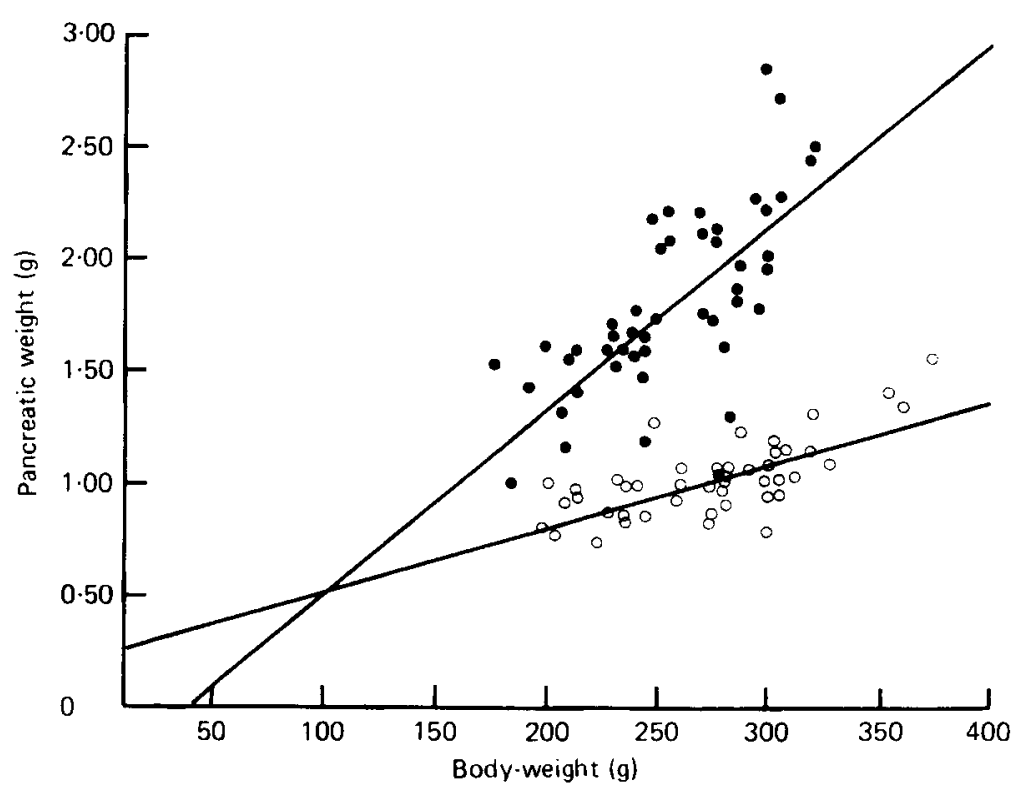

Fig. 1. Linear regression of total pancreatic wet weight $v$. total body-weight in rats fed on heated soya-bean flour (HSF) (O) and raw soya-bean flour (RSF) (O) for 36 weeks. For details of diets, see p. 120. The regression equations were: HSF-fed rats, $Y=0.0026 x+0.2599, r 0.7063$. RSF-fed rats, $Y=0.0081 x-0.2660, r 0.7094$.

RSF-fed animals was significantly greater. With cube-fed rats a significant correlation $(r=0.7003)$ between body-weight and pancreatic weight was found in animals up to 24 weeks, and the equation of the line $(Y=0.0034 x+0.0912)$ was similar to that seen in HSF-fed animals. However, if the 36 weeks values were included in the regression, the correlation coefficient fell to 0.5792 and the regression line no longer passed close to zero $(Y=0.0025 x+0.3491)$.

The linear relationship between pancreatic weight and body-weight found in RSF and HSF-fed rats over 36 weeks and cube-fed rats over 24 weeks confirms the linear relationship between these factors reported by Richards et al. (1964) in rats weighing between 100 and $400 \mathrm{~g}$. The increase in body-weight with little increase in pancreatic weight in cube-fed rats between 24 and 36 weeks is probably due to increased adipose tissue. When these animals were killed, increased fat deposits around the pancreas and other organs were apparent. In view of this variable relationship between body-weight and pancreatic weight to older cube-fed rats, pancreatic indices in this paper are expressed in terms of the total pancreas.

\section{Pancreatic DNA}

Pancreatic DNA, RNA and protein are shown in Tables 6 and 7 and the changes in DNA relative to comparable cube-fed animals are shown in Fig. 2. Pancreatic DNA was greater in RSF-fed rats than in rats fed on HSF in both the short and long term studies, and greater than that in cube-fed rats in the long-term studies. In RSF-fed animals pancreatic DNA rose to reach a plateau between 4 and 8 weeks, fell at 12 and 24 weeks and rose significantly, compared with HSF and cube-fed animals, at 36 weeks. There was no difference between pancreatic DNA in $80 \mathrm{HSF}$ and $60 \mathrm{HSF}$-fed rats. Pancreatic DNA was, however, greater in 60 HSF-fed than in HSF-fed rats in the long term study. 
Table 6. Changes in pancreatic DNA, RNA and protein content in rats after short-term feeding of raw (RSF) and heated (HSF) soya-bean flour

(Mean values with their standard errors; no. of rats in parentheses)

\begin{tabular}{|c|c|c|c|c|c|c|c|c|c|}
\hline \multirow[b]{3}{*}{ Group* } & \multirow[b]{3}{*}{ Diet* } & \multicolumn{8}{|c|}{ Period of feeding (weeks) } \\
\hline & & \multicolumn{2}{|c|}{1} & \multicolumn{2}{|c|}{2} & \multicolumn{2}{|c|}{4} & \multicolumn{2}{|c|}{8} \\
\hline & & Mean & $\mathrm{SE}$ & Mean & $\mathrm{SE}$ & Mean & $\mathrm{SE}$ & Mean & $\mathrm{SE}$ \\
\hline \multicolumn{10}{|c|}{ Total pancreatic DNA (mg) } \\
\hline 1 & Cube & 4.07 & $0.34(8) \dagger$ & & & & & & \\
\hline 2 & RSF & $4 \cdot 18$ & $0 \cdot 38(4)$ & $4 \cdot 88$ & $0-38(4)$ & $5 \cdot 74$ & $0 \cdot 38(4)$ & $5 \cdot 58$ & $0 \cdot 38(4)$ \\
\hline 3 & HSF & $4 \cdot 03$ & $0 \cdot 29(7)$ & 3.99 & $0 \cdot 38(4)$ & 4.97 & $0 \cdot 34(5)$ & $4 \cdot 26$ & $0 \cdot 26(9)$ \\
\hline \multicolumn{10}{|c|}{ Total pancreatic RNA (mg) } \\
\hline 1 & Cube & $18 \cdot 6$ & $0.7 \dagger$ & & & & & & \\
\hline 2 & $\mathrm{RSF}$ & $34 \cdot 2$ & $2 \cdot 4$ & $33 \cdot 1$ & $2 \cdot 4$ & $40 \cdot 0$ & 2.4 & $45 \cdot 9$ & $2 \cdot 4$ \\
\hline 3 & HSF & $19 \cdot 0$ & $1 \cdot 8$ & $21 \cdot 0$ & $2 \cdot 4$ & $20 \cdot 4$ & $2 \cdot 1$ & $21 \cdot 3$ & $1 \cdot 6$ \\
\hline \multicolumn{10}{|c|}{ Total pancreatic protein (mg) } \\
\hline 1 & Cube & 147 & $11 \cdot 0^{\dagger}$ & & & & & & \\
\hline 2 & RSF & 216 & $16 \cdot 0$ & 239 & $16 \cdot 0$ & 228 & $16 \cdot 0$ & 315 & $16 \cdot 0$ \\
\hline 3 & $\mathrm{HSF}$ & 135 & $12 \cdot 1$ & 155 & $16 \cdot 0$ & 145 & $14 \cdot 3$ & 157 & $10 \cdot 7$ \\
\hline
\end{tabular}

- For details, see Table 1 and p. 120.

$\dagger$ Cube-fed animals measured at the start of the study, approximately 3 months old.

Table 7. Changes in pancreatic $D N A, R N A$ and protein content in rats after long term feeding of soya-bean flour diets

(Mean values with their standard errors; no. of rats in parentheses)

\begin{tabular}{|c|c|c|c|c|c|c|c|}
\hline \multirow[b]{3}{*}{ Group* } & \multirow[b]{3}{*}{ Diet $^{*}$} & \multicolumn{6}{|c|}{ Period of feeding (weeks) } \\
\hline & & \multicolumn{2}{|c|}{12} & \multicolumn{2}{|c|}{24} & \multicolumn{2}{|c|}{36} \\
\hline & & Mean & $\mathbf{S E}$ & Mean & SE & Mean & SE \\
\hline \multicolumn{8}{|c|}{ Total pancreatic DNA (mg) } \\
\hline 1 & Cube & $3 \cdot 32$ & $0 \cdot 46(8)$ & 3.65 & $0.49(9)$ & $3 \cdot 62$ & $0.53(6)$ \\
\hline 2 & RSF & $3 \cdot 76$ & $0 \cdot 37(12)$ & 4.09 & $0.43(9)$ & $6 \cdot 73$ & $0 \cdot 39(11)$ \\
\hline 3 & HSF & $2 \cdot 80$ & $0.53(6)$ & 3.71 & $0.46(8)$ & $3 \cdot 51$ & $0.46(8)$ \\
\hline 4 & $80 \mathrm{HSF}$ & $3 \cdot 93$ & $0.53(6)$ & $4 \cdot 10$ & $0 \cdot 46(8)$ & $4 \cdot 00$ & $0 \cdot 46(8)$ \\
\hline 5 & $60 \mathrm{HSF}$ & $5 \cdot 01$ & $0 \cdot 46(8)$ & $4 \cdot 20$ & $0.46(8)$ & 4.98 & $0.49(8)$ \\
\hline \multicolumn{8}{|c|}{ Total pancreatic RNA (mg) } \\
\hline 1 & Cube & 19.9 & $2 \cdot 4$ & $22 \cdot 8$ & $2 \cdot 6$ & $20 \cdot 8$ & $2 \cdot 8$ \\
\hline 2 & RSF & $36 \cdot 9$ & $2 \cdot 0$ & $36 \cdot 8$ & $2-3$ & 43.9 & $2 \cdot 1$ \\
\hline 3 & HSF & $18 \cdot 9$ & $2 \cdot 8$ & $20 \cdot 3$ & $2 \cdot 4$ & $21 \cdot 9$ & $2 \cdot 4$ \\
\hline 4 & $80 \mathrm{HSF}$ & $23 \cdot 6$ & $2 \cdot 8$ & 27.9 & $2 \cdot 4$ & $29 \cdot 2$ & $2 \cdot 4$ \\
\hline 5 & $60 \mathrm{HSF}$ & $34 \cdot 9$ & $2 \cdot 4$ & $31 \cdot 3$ & $2 \cdot 4$ & $35 \cdot 8$ & $2 \cdot 5$ \\
\hline \multicolumn{8}{|c|}{ Total pancreatic protein (mg) } \\
\hline 1 & Cube & 190 & $22 \cdot 4$ & 201 & $23 \cdot 9$ & 182 & $25 \cdot 8$ \\
\hline 2 & RSF & 310 & $18 \cdot 3$ & 238 & $21 \cdot 1$ & 357 & $19 \cdot 1$ \\
\hline 3 & $\mathrm{HSF}$ & 128 & $25 \cdot 8$ & 163 & $22 \cdot 4$ & 154 & $22 \cdot 4$ \\
\hline 4 & $80 \mathrm{HSF}$ & 215 & $25 \cdot 8$ & 230 & $22 \cdot 4$ & 219 & $22 \cdot 4$ \\
\hline 5 & $60 \mathrm{HSF}$ & 370 & $22 \cdot 4$ & 264 & $22 \cdot 4$ & 263 & $23 \cdot 9$ \\
\hline
\end{tabular}

* For details, see Table 1 and p. 120. 


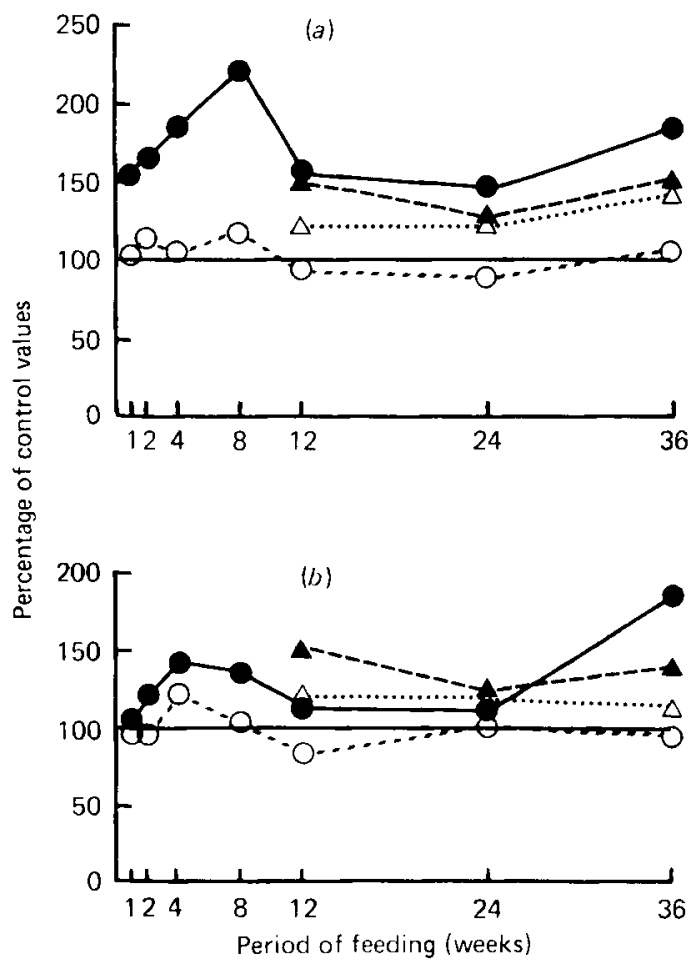

Fig. 2. Changes in (a) pancreatic weight and (b) DNA during the feeding of raw soya-bean flour (RSF) (O), heated soya-bean flour (HSF) (O), $200 \mathrm{~g} \mathrm{RSF}+800 \mathrm{~g} \mathrm{HSF} / \mathrm{kg}(80 \mathrm{HSF})(\triangle)$ and $400 \mathrm{~g} \mathrm{RSF}+600 \mathrm{~g}$ $\mathrm{HSF} / \mathrm{kg}(60 \mathrm{HSF})(\boldsymbol{A})$ for 36 weeks. For details of diets, see p. 120. Values are expressed as a percentage of control values taken from comparable cube-fed rats.

\section{Pancreatic RNA and protein}

Changes in pancreatic RNA and protein relative to comparable cube-fed rats are shown in Fig. 3. These values followed a pattern similar to that seen with pancreatic weight and DNA. Significant differences were seen with all the dietary comparisons listed in Table 3. Thus, in the long term studies, RNA and protein were both higher in RSF-fed compared with HSF-fed animals, in $60 \mathrm{HSF}$ compared with 80-HSF-fed animals, in $60 \mathrm{HSF}$ compared with HSF-fed animals and in RSF compared with cube-fed animals.

In the RSF-fed and $60 \mathrm{HSF}$-fed animals pancreatic protein fell considerably between 12 and 24 weeks while in the other groups no such fall was seen (Table 7). Pancreatic protein then rose again in RSF-fed rats between 24 and 36 weeks. It is this differential change in pancreatic protein which leads to the significant interaction shown for pancreatic protein in the long term studies in Table 3.

\section{Effect of RSF diet in old rats (group 6)}

The fall in pancreatic weight and other indices in RSF-fed animals at 12 and 24 weeks suggested the possibility that the trophic response to RSF was weak in older animals. The experiment using older animals (group 6) was therefore performed to test this. The results are shown in Table 8 . These animals showed a trophic response similar to that seen in the early stages of RSF feeding to young rats (group 2). 


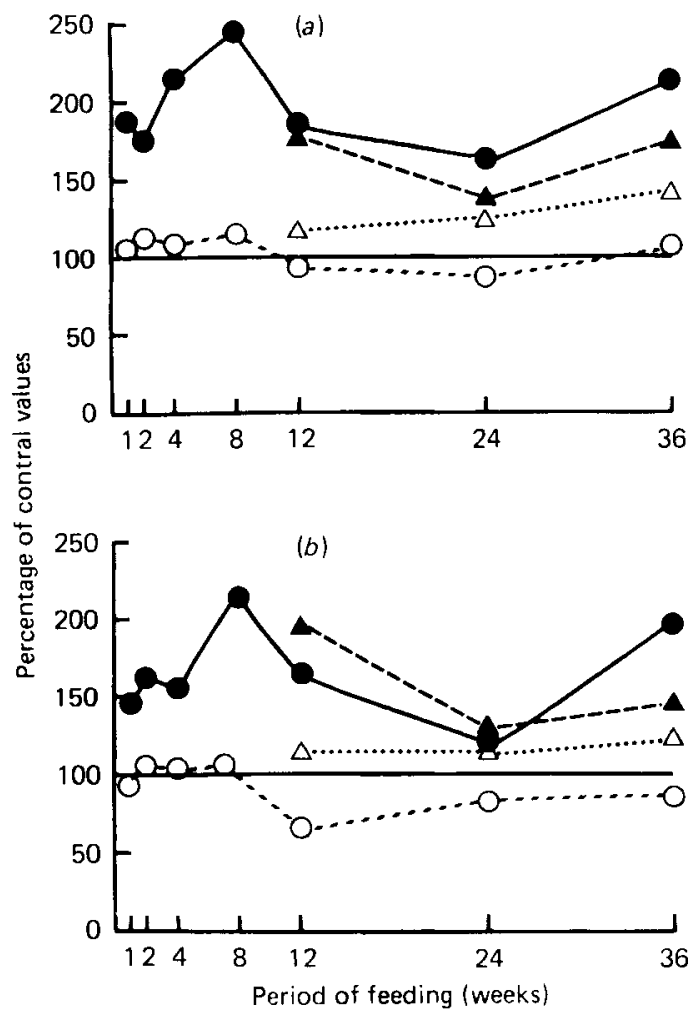

Fig. 3. Changes in (a) RNA and (b) protein during the feeding of raw soya-bean flour (RSF) (O), heated soya-bean flour $(\mathrm{HSF})(\mathrm{O}), 200 \mathrm{~g} \mathrm{RSF}+800 \mathrm{~g} \mathrm{HSF} / \mathrm{kg}(80 \mathrm{HSF})(\triangle)$ and $400 \mathrm{~g} \mathrm{RSF}+600 \mathrm{~g} \mathrm{HSF} / \mathrm{kg}$ $(60 \mathrm{HSF})(\Delta)$ for 36 weeks. For details of diets, see p. 120. Values are expressed as a percentage of control values taken from comparable cube-fed rats.

Table 8. Pancreatic indices in old rats fed on raw soya-bean flour ( $R S F$ )

(Mean values with their standard errors; animals were 14 months old when tested)

\begin{tabular}{|c|c|c|c|c|c|c|}
\hline Dietary regimen & $\begin{array}{l}\text { No. of } \\
\text { rats }\end{array}$ & $\begin{array}{c}\text { Body-wt } \\
\text { (g) }\end{array}$ & $\begin{array}{c}\text { Pancreatic } \\
\text { wt } \\
\text { (g) }\end{array}$ & $\begin{array}{l}\text { DNA } \\
(\mathrm{mg})\end{array}$ & $\begin{array}{l}\text { RNA } \\
(\mathrm{mg})\end{array}$ & $\begin{array}{l}\text { Protein } \\
\text { (mg) }\end{array}$ \\
\hline 2 weeks on RSF & 5 & $359 \pm 15.9$ & $2 \cdot 104 \pm 0 \cdot 195$ & $4.72 \pm 0.28$ & $46 \cdot 00 \pm 4 \cdot 3$ & $401 \pm 42 \cdot 4$ \\
\hline Control (rat cubes) & 4 & $367 \pm 17.8$ & $1.329 \pm 0.077$ & $4.03 \pm 0.18$ & $25 \cdot 63 \pm 1.7$ & $219 \pm 12 \cdot 5$ \\
\hline $\begin{array}{l}\text { Statistical } \\
\text { significance of } \\
\text { difference: } P\end{array}$ & & NS & $<0.05$ & NS & $<0.01$ & $<0.01$ \\
\hline 4 weeks on RSF & 4 & $388 \pm 6 \cdot 3$ & $2.330 \pm 0.049$ & $6.97 \pm 0.27$ & $58 \cdot 7 \pm 1 \cdot 6$ & $509 \pm 28 \cdot 4$ \\
\hline Control (rat cubes) & 5 & $387 \pm 30 \cdot 1$ & $1 \cdot 142 \pm 0.026$ & $5 \cdot 36 \pm 0.42$ & $27 \cdot 20 \pm 0.6$ & $204 \pm 4.9$ \\
\hline $\begin{array}{l}\text { Statistical } \\
\text { significance of } \\
\text { difference: } P\end{array}$ & & NS & $<0.001$ & $<0.05$ & $<0.001$ & $<0.001$ \\
\hline
\end{tabular}

NS, not significant. 
DISCUSSION

These studies suggest that raw-soya-bean feeding produces both hypertrophy and hyperplasia of the pancreas. Increases in pancreatic weight, RNA and protein in comparison with DNA can be used as an index for hypertrophy (Johnson, 1976; Melmed et al. 1976). DNA as a measure of cell number is used as the index for hyperplasia. The hypertrophic response in RSF-fed rats is very rapid with a significant rise in pancreatic weight, RNA and protein within 1 week while the hyperplastic response is slower.

After 8 weeks on RSF, pancreatic DNA was approximately $140 \%$ that of comparable control (cube-fed) animals, while pancreatic weight, protein and RNA were approximately $230 \%$ of control. If DNA content per cell remains constant this indicates an increase in cell number of $40 \%$ with each cell approximately $60 \%$ larger. Although a detailed morphometric study of the pancreas in RSF-fed animals has not been performed, a number of workers have reported increased acinar cell size in rats fed on RSF (Booth et al. 1960; Saxena et al. 1963; Beswick et al. 1971).

In RSF-fed rats all pancreatic indices peaked at 8 weeks and then declined, to rise again at 36 weeks. The fall in the 12 and 24 week rats may be due to a decreasing sensitivity of the pancreas to RSF as a result of age, or as a result of continued stimulation, or to an effect of prolonged malnutrition. The first of these possibilities seems unlikely since old rats acutely exposed to RSF responded with pancreatic growth similar to that seen in the younger animals (Tables 4,6). Previous workers have also shown that adult animals respond to this diet with pancreatic enlargement (Booth et al. 1964). The second possibility, that continued exposure to high levels of cholecystokinin (CCK; the trophic hormone thought to be released by trypsin inhibitor) might desensitize the pancreas to the effects of this hormone, also seems unlikely. Secretion studies in these animals have not shown any loss of sensitivity to high doses of exogenous CCK over the 36 week test period (Crass and Morgan, unpublished results). The most likely explanation is that the reduction in pancreatic size is an effect of general malnutrition. After 12 weeks on the RSF diet the rats are thinner and more lethargic than the cube-fed controls, with a marked 'limpness ' when handled. Body-weight is significantly reduced. RSF is low in methionine (Hayward \& Hafner, 1941) and this deficiency is exacerbated by the increased secretion of sulphurcontaining amino acids in the pancreatic juice (Barnes et al. 1965). Multiple deficiencies in amino acids occur in animals fed on RSF and account for the growth-suppressing properties of this diet (Haines \& Lyman, 1961). Pancreatic atrophy in animals fed on diets deficient in protein or amino acids has been frequently reported (Sidransky \& Farber, 1958; Scott \& Vermillion, 1966).

The rise in pancreatic indices at 36 weeks may reflect increased body growth (Table 5) or the beginning of adenomatous changes. Adenomatous changes have been previously reported in rats fed on RSF longer than 30 weeks (McGuinness et al. 1980) and hyperplastic pancreatic nodules were also seen in the present study in RSF-fed animals at 36 weeks, even in the absence of azaserine.

Animals fed on $80 \mathrm{HSF}$ and $60 \mathrm{HSF}$ showed pancreatic enlargement commensurate with the RSF content. After feeding rats a diet containing $400 \mathrm{~g} \mathrm{RSF} / \mathrm{kg}$ (60 HSF-fed animals) there was a small hyperplastic response along with a greater hypertrophic response.

It is possible that the changes in DNA seen in animals fed on RSF reflect changes in DNA content per cell rather than changes in cell number. Light microscopy of the pancreas from these animals shows numerous apparently binuclear cells. It has been shown by Bourdel and co-workers that dietary manipulation can lead to polyploidy in the pancreas with binucleation as the first step in this process (Bourdel et al. 1971). Nevertheless, even if the changes in DNA level seen in RSF-fed animals are due to increased DNA per cell, rather 
than to increased cell number, an increased susceptibility of the cell to damage by carcinogens during the period of increased DNA production could be expected.

This work was supported by a grant from the National Health and Medical Research Council of Australia.

\section{REFERENCES}

Barnes, R. H., Fiala, G. \& Kwong, E. (1965). J. Nutr. 85, 127.

Beswick, I. P., Pirola, R. C. \& Bouchier, I. A. D. (1971). Br. J. exp. Path. 52, 252.

Booth, A. N., Robbins, D. J., Ribelin, W. E. \& DeEds, F. (1960). Proc. Soc. expl. Biol. Med. 104, 681.

Booth, A. N., Robbins, D. J., Ribelin, W. E., DeEds, F., Smith, A. K. \& Rackis, J. J. (1964). Proc. Soc. expl Biol. Med. 116, 1067.

Bourdel, G., Girard-Globa, A. \& Forestier, M. (1971). Lab. Invest. 25, 331.

Bredenkamp, B. L. F. \& Luck, D. N. (1969). Proc. Soc. expl Biol. Med. 132, 537.

Chernick, S. S., Lepkovsky, S. \& Chaikoff, I. L. (1948). Am. J. Physiol. 155, 33.

Dockray, G. J. (1972). J. Physiol., Lond. 225, 679.

Fölsch, U. R., Winckler, K. \& Wormsley, K. G. (1974). Digestion, 11, 161.

Fölsch, U. R. \& Wormsley, K. G. (1974). Scand. J. Gastroenterol. 9, 679.

Haines, P. C. \& Lyman, R. L. (1961). J. Nutr. 74, 445.

Hatcher, D. W. \& Goldstein, G. (1969). Analyt. Biochem. 31, 42.

Hayward, J. W. \& Hafner, F. H. (1941). Poultry Sci. 20, 139.

Hutchison, W. C. \& Munro, H. N. (1961). Analyst, Lond. 86, 768.

Johnson, L. R. (1976). Gastroenterology 70, 278.

Kakade, M. L., Simons, N. R. \& Liener, I. E. (1969). Cereal Chem. 46, 518.

Konijn, A. M. \& Guggenheim, K. (1967). Proc. Soc. expl Biol. Med. 126, 65.

Levison, D. A., Morgan, R. G. H., Brimacombe, J. S., Hopwood, D., Coghill, G. \& Wormsley, K. G. (1979). Scand. J. Gastroenterol. 14, 217.

McGuinness, E. E., Morgan, R. G. H., Levison, D. A., Frape, D. L., Hopwood, D. \& Wormsley, K. G. (1980). Scand. J. Gastroenterol. 15, 497.

Madar, J. \& Klein, M. (1979). Nutr. Metab. 23, 117.

Melmed, R. N., El Aaser, A. A. A. \& Holt, J. J. (1976). Biochim. biophys. Acta 421, 280.

Morgan, R. G. H., Levison, D. A., Hopwood, D., Saunders, J. H. B. \& Wormsley, K. G. (1977). Cancer Letters 3, 87.

Munro, H. N. \& Fleck, A. (1966). Analyst, Lond. 91, 78.

Rackis, J. J. (1965). Fedn Proc. Fedn Am. Socs exp. Biol. 24, 1488.

Richards, C., Fitzgerald, P. J., Carol., B., Rosenstock, L., Lipkin, L. (1964), Lab. Invest. $13,1303$.

Salman, M. H., Pubols, M. H. \& McGinnis, J. (1968). Proc. Soc. expl Biol. Med. 128, 258.

Saxena, H. C., Jensen, L. S., McGinnis, J. \& Lauber, J. K. (1963). Proc. Soc. expl Biol. Med. 112, 390.

Schacterle, G. R. \& Pollack, R. L. (1973). Analyt. Biochem. 51, 654.

Scott, E. B. \& Vermillion, S. D. (1966). Archs Path. 82, 119.

Sidransky, H. \& Farber, E. (1958). Archs Path. 66, 119. 